\title{
O DIREITO DE SUPERFÍCIE NA PROMOÇÃO DA REFORMA AGRÁRIA BRASILEIRA (POSSIBILIDADES E VANTAGENS)
}

Roberto Wagner MarquesI

Doutor e Mestre em Direito Civil pela Faculdade de Direito do Largo São Francisco - USP. Mestre em Direito Civil pela Universidade Estadual de Londrina.

Ana Cláudia Corrêa Zuin Mattos do Amaral Doutora em Direito Civil Comparado pela Pontifícia Universidade Católica de São Paulo. Mestre em Direito Civil pela Universidade Estadual de Londrina.

\section{Resumo}

Este artigo aborda as possibilidades e vantagens da aplicaçáo do direito real de superfície na execução da Reforma Agrária no Brasil. Pesquisa, para tanto, a questão agrária brasileira, desde o Descobrimento do País até os dias atuais. Examina a questâo agrária à luz do trinômio latifúndio/minifúndio/violência. Investiga a estrutura do direito de superfície, tratando de seu conceito, características, evolução histórica e função socioeconômica. Aborda os métodos eleitos pelo Estado Brasileiro para a execução da Reforma Agrária. Apresenta o direito de superfície, em sede de conclusão e à luz da norma civil, agrária e constitucional, como instituto dotado de grande potencial socioeconômico e instrumento capaz de contribuir para a promoção da Reforma Agrária no território brasileiro. Em proposta de lege ferenda, sugere a alteração do Estatuto da Terra, para o fim de incluir a superfície como um dos mecanismos para a promoção da Reforma Agrária no Brasil.

\section{Palavras-chave}

Direito Civil; Superfície; Reforma Agrária.

\section{Resumen}

Este artículo analiza las posibilidades y ventajas de la aplicación del derecho real de superficie en la implementación de la reforma agraria en Brasil. Investiga, así, la cuestión agraria brasileña, desde el descubrimiento del país hasta nuestros días. Examina la cuestión agraria a la luz de la grande propiedad/pequeńa propiedad / violencia. Analiza la estructura del derecho de superficie, su concepto, características, desarrollo histórico y 
la función socio-económica. Discute, además, los métodos elegidos por el Estado brasileño para la implementación de la reforma agraria. En conclusión, muestra el derecho de superficie con base en la norma civil, agraria y constitucional, como instituto con un gran potencial socioeconómico y instrumento capaz de contribuir a la promoción de la reforma agraria en Brasil. Una propuesta de lege ferenda, sugiere que se modifique el Estatuto de la Tierra, con el fin de incluir la superficie como uno de los mecanismos para promover la reforma agraria en Brasil.

\section{Palabras clave}

Derecho Civil; Superficie; Reforma Agraria.

\section{Introdução}

O território brasileiro compóe cerca de quarenta por cento da superfície física da América do Sul. Sua dimensão equipara-se à do Continente Europeu, sendo certo que o País, que se estende por zona tropical, conta com mais de quatrocentos milhóes de hectares aptos para a prática da agropecuária. Compreende-se, portanto, a importância que o setor primário da economia representa para a nação.

Apesar disso e a despeito de o País vir colecionando recordes mundiais nas safras de grãos, o espaço fundiário brasileiro apresenta graves problemas estruturais e sociais, consubstanciados nas figuras do latifúndio e do minifúndio e na questão dos conflitos pelo acesso à terra. Enquanto os dois primeiros vão contra a ideia da democratização e da função socioeconômica da propriedade, a violência no campo tem deixado dezenas de vítimas fatais ano após ano.

A esses três fatores, que diferenciam o perfil agrário do País das naçóes do Hemisfério Norte, convencionou-se chamar "questão agrária brasileira", um problema de âmbito nacional e cuja solução é objetivo primaz da Reforma Agrária.

Embora realize hoje a maior reforma fundiária do Planeta, o Brasil não tem conseguido resolver ou mesmo atenuar os efeitos da questão agrária. Isso demanda do pesquisador investigação científica para apurar por que razão a política fundiária não tem atingido seus escopos, que, por definição legal, são o de reduzir o número de latifúndios e minifúndios e fazer cessar os conflitos no campo.

O trabalho aqui empreendido examina a formação do perfil fundiário brasileiro, entrelaçando-a aos conflitos pelo acesso à terra e buscando os fatores pelos quais a questão agrária se consolidou no País. A partir daí, parte para o exame da política de Reforma Agrária e dos instrumentos legais concebidos para sua execução.

Com o advento da superfície agrária na codificação de 2002 e sua grande semelhança com a propriedade, o que faz dela um instituto apto a cumprir uma função 
socioeconômica, este trabalho indaga de suas possibilidades e vantagens na execução da Reforma Agrária.

A abordagem aqui empreendida é interdisciplinar, ancorada na norma civil, agrária e constitucional. O diálogo entre esses ramos do Direito é necessário, eis que as figuras jurídicas aqui envolvidas estão presentes em todos eles. Trata-se de estudo feito à luz da legalidade constitucional, que toma em apreço os objetos da República Federativa do Brasil presentes no Texto de 1988.

\section{A Questão Agrária Brasileira}

Colonizado a partir de 1534, quando da instalação das Capitanias Hereditárias, o território brasileiro apresenta singular convivência de latifúndios com minifúndios. Forte na Lei 8.629/93, que, ao lado da Lei 4.504/64, disciplina a Reforma Agrária no Brasil, consideram-se latifúndios todas as áreas maiores que seiscentos módulos fiscais. Considerando que o módulo fiscal, nas regióes mais desenvolvidas do País, é de cerca de dez hectares, resulta serem latifundiárias as propriedades superiores a seis mil hectares. Os minifúndios, de seu turno, são todas as propriedades inferiores às dimensões do módulo fiscal.

O módulo fiscal, por definição contida na primeira das leis citadas, é a área de terras imprescindível para que uma família consiga manter um mínimo existencial. Segue, portanto, que tanto os latifúndios quanto os minifúndios são elementos nocivos ao ambiente fundiário. Os primeiros são indesejados porque concentram a propriedade nas mãos de poucos, enquanto os segundos são imóveis que não bastam para sustentar uma família, sendo por isso chamados parvifúndios, ou propriedades pobres.

Com efeito, dados os males que uns e outros causam, são ambos hostilizados pelo Direito. Isso se colhe com clareza da referida Lei 4.504/64 (Estatuto da Terra), que os considera prioritários para desapropriação para fins de Reforma Agrária (art.20), sendo certo, ainda, que, em relação aos minifúndios, estão vedados os desmembramentos e divisôes imobiliários que venham a gerá-los.

É consenso doutrinário que as figuras em questão são nocivas e que sua redução é medida que se impóe. É conhecida a afirmação de BORGES (2000, p. 16), para quem o minifúndio, por não ser bastante para propiciar à família que o explora condições dignas de vida, é "uma praga". E não é apenas no Brasil que eles são um entrave ao desenvolvimento do campo. Em solo mexicano verifica-se idêntico problema:

No minifúndio existem estagnação e imperfeições técnicas que se traduzem em produção insuficiente, baixa produtividade, relaçóes de intercâmbio desfavoráveis e níveis de vida inaceitáveis. Por isso a maioria dos produtores e trabalhadores vive em condições de pobreza (MOGUEL: 1992, p. 269, livre tradução). 
O latifúndio, por sua vez, é tido igualmente como nocivo pela doutrina, como se vê, por exemplo, em FREIRE (1998, p. 29). Eles não apenas concentram a propriedade, como também apresentam, na grande maioria dos casos, baixos índices de produtividade. Na opiniấo de PEIXOTO NETO (2013, p. 15.340), a figura em análise

representa a consagração da produção extensiva de baixo nível tecnológico, com uso inadequado das reais potencialidades para a promoção do bem-estar social, contribuindo para a manutenção das desigualdades históricas no meio rural brasileiro, inclusive restringindo de forma excessiva o acesso à terra, que distorce os valores do imóvel rural, criando uma verdadeira bolha imobiliária agrária.

Sem embargo, informaçóes do Atlas da Terra 2015, divulgado pelo CNPq/USP, revelam que cerca de 47 por cento de todo o espaço agrário brasileiro encontra-se nas máos de apenas 130 mil proprietários, o que faz do Brasil campeão mundial em número de latifúndios, atrás apenas do Paraguai. Já os minifúndios são em número superior a 37 milhões de propriedades, ocupando cerca de 9 por cento do território (MST, 2015, sem página).

A violência no ambiente rural, de seu turno, é inquietante e preocupa. Num espaço de menos de três décadas, ou seja, entre 1985 a 2013, somente o Estado do Pará registrou 645 mortes nos conflitos pela terra, enquanto o Maranhão contou 138 vítimas (MACEDO, 2015, sem página). No ano de 2013, conflitos pela posse da terra em todo país ceifaram 34 vidas (CARVALHO, 2014, p. 1).

É interessante assinalar que a maioria dos conflitos envolvendo a terra tem ocorrido na Regiâo Nordeste, que, a par de apresentar altos índices de pobreza e baixa qualidade de vida, ostenta grande números de latifúndios e minifúndios. De 1985 a 2014, 10.488 conflitos tiveram lugar nessa Região (ALENCAR; CUNHA; MATOS, 2015, p. 69).

Nesse passo, no período de 1985 a 2014, mais de dezenove milhóes de pessoas estiveram envolvidas na questão agrária brasileira, o que representa cerca de dez por cento da população (ALENCAR, 2015, p. 69), número sem dúvida impressionante. É sintomático que a Região Sul foi a que menos registrou conflitos. Justamente o espaço brasileiro que menos concentra latifúndios e minifúndios.

Diante disso, é possível afirmar que as figuras do latifúndio e do minifúndio guardam conexão com os conflitos pela posse da terra. É de grande importância, para os propósitos do trabalho aqui empreendido, saber como a estrutura fundiária do Brasil chegou à condição atual. Para isso serão examinados os três fatores que compóem a dita questão agrária.

\subsection{Nascimento e Consolidação dos Latifúndios}

Descoberto o Brasil em 1500 e diante da frustração com a inexistência de metais preciosos, não se interessaram os portugueses pela ocupação e povoamento das novas 
terras. Seu interesse, como é sabido, só seria despertado com a notícia da descoberta das minas de prata no interior do Continente e com a presença de embarcaçóes espanhola nas costas do Atlântico.

Em 1534 surge o sistema das donatarias, que consistia na concessão de gigantescas porçóes de terra, chamadas Capitanias, a figuras da nobreza portuguesa. Quinze foram as Capitanias instaladas no Brasil. Sobre elas, exercia o titular poderes de grande amplitude, inclusive o de administração e jurisdição.

Um dos poderes de que dispunha o capitão donatário, e que está na base da questão agrária brasileira, era o de conceder sesmarias. Estas são uma forma de propriedade sobre enormes superfícies agrárias, geralmente envolvendo milhares de hectares e que impunham ao titular, o sesmeiro, obrigaçóes de ocupação e exploração (LIBERATO, 2003, p. 36).

Ocorre que o sistema das sesmarias, conquanto exitoso nas ilhas portuguesas do Atlântico, não apresentou bons resultados no Brasil. A esse sistema se pode atribuir o surgimento dos latifúndios no País. De fato, as sesmarias apresentaram dois grandes problemas: primeiro, sua extensão territorial tornava inviável ocupação e exploraçáo; segundo, os titulares a quem eram concedidas não se interessavam pelas terras, seja porque imbuídos de intenção especulativa seja por não possuírem recursos econômicos suficientes para explorá-las.

Com efeito, o modelo adotado pelos colonizadores foi, desde o início, o do grande latifúndio. Aqui já se vê um contraste com a colonização britânica efetuada na Costa Leste dos Estados Unidos, baseada nas pequenas propriedades. A experiência portuguesa nas ilhas atlânticas foi exitosa porque havia poucas terras e muitos habitantes dispostos a colonizar. Aqui, as condiçôes eram inversas. Havia grande disponibilidade de terras e escasso contingente de pessoas dispostas a ocupá-las (PRADO JR, 1969, p. 20).

Outro ponto negativo do latifúndio repousava na figura de seu titular. O sesmeiro português não se interessava por vir ao Brasil, ocupar a terra e torná-la produtiva. Antes, era intenção sua manter as terras como reserva de valor, para mais tarde aliená-las a preços vantajosos, em nítido escopo especulativo. Intenção de trabalho não havia, o que vale a dizer que o português parece ter querido colher os frutos antes de plantar a árvore (HOLANDA, 1995, p. 44).

Aqui há outro contraste com o povoamento dos Estados Unidos. Os colonizadores da América do Norte, fugindo a perseguiçôes religiosas em seus países de origem, não tinham opção senão radicar-se nas terras recém-descobertas, ali fixando sua moradia permanente e explorando a terra como forma de sobrevivência. Não lhes animava a ideia de retorno à Pátria. O futuro estava no Novo Mundo.

Os anglo-saxôes foram para a América do Norte não em busca de riqueza fácil. Movia-os a hostilidade de que eram vítimas em sua pátria de origem, de onde emigravam 
na busca de terra onde pudessem cultuar o seu Deus, ler e interpretar a sua Bíblia, trabalhar, ajudarem-se uns aos outros...pois, ao embarcarem, trazendo consigo todos os haveres, mulheres e filhos, deram as costas à Europa, para fundar deste lado do Atlântico uma nova pátria, a pátria teocrática dos calvinistas (MOOG, 1974, p. 88).

Isso não aconteceu com o colonizador português, que jamais demonstrou apego pelas terras recém-descobertas. Ao contrário, mesmo tenho recebido em doação significativos espaços rurais, não se animaram a vir ao Brasil. Pode-se dizer que esse espírito foi uma constante na colonização da América Latina. Exemplo emblemático está em Cortez, o colonizador espanhol no México, que, em notória passagem histórica, sentenciou: "Não vim aqui para trabalhar como um labrego, mas para buscar ouro".

Não fosse por isso, o sesmeiro português jamais contou com o concurso econômico da metrópole, que nada mais fez senão doar as terras. Como os sesmeiros já desfrutavam de boa condiçáo de vida na Corte, compreende-se seu descaso para com as sesmarias.

Resultado disso é que, ao chegar a Independência, o território brasileiro é uma mescla de enormes propriedades rurais desocupadas ou deficientemente ocupadas.

De fato, quatro são os fatores que caracterizam a situação fundiária brasileira em 1822: a) a população é diminuta, comparada à imensidade do território; $b$ ) as terras estão quase todas repartidas e as que restam estão sujeitas às incursôes indígenas; $c$ ) os grandes proprietários rurais, ainda com propósitos de especulação, proíbem o ingresso de famílias para promover a exploração das terras; $d$ ) existem muitas famílias vagando de um lugar a outro, sem terras para se fixar ou meios para adquirir glebas exploráveis (DIAS, apud FAORO, 1991, p. 10).

Entende-se, diante disso, que o sistema aqui adotado tenha fracassado. Em 1822, pouco antes da Independência, o modelo sesmarial é extinto, mas seus efeitos perdurarão até os dias presentes, traduzidos na figura do latifúndio de baixa produtividade.

\subsection{Nascimento e Consolidação dos Minifúndios}

Com a Independência em 1822, o Brasil, que até entáo se submetia ao direito lusitano, investe-se no poder de criar seu próprio ordenamento jurídico. Contudo, em relação à propriedade agrária, a primeira disposição normativa só surgirá em 1850, com a edição da Lei 601, conhecida como Lei de Terras. Isso significa que, nesse espaço de três décadas, não houve qualquer disciplina jurídica regulando o acesso à terra.

Esse período de tempo, que vai da Independência ao advento da Lei 601/1850, é o chamado "regime de posses", assim rotulado porque a ocupação se converte no meio padrão de aquisição da terra. Desaparece a figura do título de propriedade, que, como é 
cediço, sempre decorre da lei. O fato substitui o direito. Posse, e náo mais propriedade, passa a ser o mecanismo de acesso à terra (LIMA, 1998, p. 34).

Ocorre que a Lei 601/1850, dentre várias disposiçôes normativas, legitimou as posses obtidas naquele trintênio. Assim, quem demonstrasse o exercício da posse e a presença de um documento de concessão acabava por adquirir o domínio. É, sem dúvida, uma forma de usucapião. Essa disposição normativa talvez tenha sido concebida com boas intenções, com o propósito de estimular a ocupação e a produtividade, mas teve efeito contrário.

É que, após, 1850, seguiu-se um período de fraudes e violência. Determinados sujeitos, ávidos de acumular patrimônio, iniciam a prática da "grilagem" de documentos. O método, revelador de falsidade ideológica, consistia num simulacro de carta de concessáo de sesmaria. Tratava-se de redigir um documento, com aparência de oficial, pré-datado de muitas décadas e submetido a um processo rústico de envelhecimento (o documento era depositado numa gaveta, onde se aprisionavam grilos). Depois de algumas semanas, o documento, pela açáo dos insetos, aparentava ser velho.

O documento grilado servia como prova para legitimar a posse, que era assim convertida em propriedade. A partir daí, exibindo seu título, o sujeito punha-se a desalojar os ocupantes das terras agora legitimadas. Nasce aí uma figura igualmente emblemática do período, é dizer, o "jagunço", pessoa encarregada de expulsar aqueles que ocupavam as terras legitimadas.

Oprimidos diante da violência, os colonos que haviam fixado moradia e que se achavam a explorar as terras não tinham alternativa senão abandoná-las. Vão, então, clandestinamente, instalar-se nas bordas do latifúndio, em pequenos espaços onde moram a mantêm uma lavoura de subsistência, longe dos olhos do dono da terra.

A legitimação de posses estimula e consolida assim os minifúndios, que, ao lado dos latifúndios, caracterizarão o perfil fundiário brasileiro após 1850 .

\subsection{Conflitos pela Posse da Terra}

O terceiro dos problemas que afligem o campo é o da violência, que se intensifica com a referida Lei 601/1850. Esta, como acima se viu, culminou por arraigar no país latifúndios e minifúndios e, não fosse por isso, proibiu novas doaçóes públicas de terra, o que tornou a propriedade praticamente inacessível às classes não abastadas.

Com o advento da Independência e o vazio legal que se seguiu, as classes campesinas póem-se gradativamente a se rebelar. Ocorre, entâo, a partir de 1823, uma série de conflitos pelo território nacional. Assinala-se, nesse ano, a Cabanagem, no Pará. Depois, em 1836, eclode a Revolução Farroupilha, no Rio Grande do Sul. Em 1837, na Bahia, tem 
lugar a Sabinada. Já em 1841 estoura a Balaiada, envolvendo os Estados do Piauí, Maranhão e Ceará. Em 1893, vem à tona a Guerra de Canudos, na Bahia e, 1912, a Guerra do Contestado, nos Estados do Paraná e de Santa Catarina (VARELLA, 1998, p.132 e ss.).

O pano de fundo de todas essas revoltas foi a luta pela terra. Tome-se o significativo exemplo da Guerra de Canudos. Expulsos de suas possessóes, milhares de colonos e de ex-escravos vão se refugiar no interior da Bahia e, a partir daí, promover invasóes naquela região. Os confrontos daí advindos, tendo, de um lado, os acampados e, de outro, forças públicas e milícias organizadas por latifundiários, resultarão em cerca de 25 mil mortos (CUNHA, 2000, p. 491).

Outro exemplo digno de nota é o da Guerra do Contestado. Sua gênese está na doação feita pelo Governo Federal à empresa britânica Brasil Railway Company, que, tendo construído uma ferrovia ligando aqueles Estados do Sul, recebeu em pagamento as terras localizadas numa faixa de trinta quilômetros ao longo de toda a linha férrea. Os agricultores que ocupavam essa área e que não detinham título de propriedade foram expulsos pelo Governo, nascendo daí a revolta que resultaria na morte de centenas de agricultores (ALMEIDA JR, 2011, p. 44).

Embora em intensidade menor, os conflitos agrários seguiram no Século XX. Nos anos sessenta, uma campanha de invasóes à propriedade rural desenvolveu-se no Sul e no Nordeste, com o apoio do Partido Comunista Brasileiro. Os conflitos só seriam encerrados com a Revoluçáo de 1964, quando os militares tomam o poder no País.

Houve relativa paz no campo durante vinte anos. Mas, com a reabertura política em 1985, os conflitos pela posse da terra recrudesceram em todas as regióes do País. Em 1985, quando do surgimento do lago de Itaipu e consequente desapropriação dos imóveis ribeirinhos a preços menores que os de mercado, é fundado o Movimento dos Trabalhadores Rurais Sem-Terra (MST). Este organismo, que este ano completa trinta anos de existência, nasceu com o propósito declarado de forçar o Poder Público a implementar e executar a Reforma Agrária no Brasil.

Dentre os métodos empregados pelo MST, sobressai o das invasões, meio pelo qual se pratica o esbulho. Outro meio muito empregado pelo organismo é o da ocupação de praças e edifícios públicos e o bloqueio de rodovias e de pedágios. Os conflitos daí resultantes mostraram-se nefastos em alguns casos, como no episódio de Eldorado do Carajás, em 1999, quando dezenove manifestantes foram mortos pela Polícia. No mesmo ano, 44 pessoas perderam a vida em conflitos agrários (MARQUESI, 2009, p. 134).

Expostos assim os fatos, colhe-se a conclusão de que o território brasileiro, composto por grande número de latifúndios e de minifúndios, é um ambiente inseguro, o que impóe a necessidade de planejamento e execução de uma política de Reforma Agrária. 


\section{Reforma Agrária}

Para atingir o escopo da presente investigação, impende examinar, ainda que sucintamente, duas questóes referentes à Reforma Agrária, ou seja, sua natureza de direito fundamental e os mecanismos eleitos pelo legislador para sua consecução.

\subsection{Fundamentalidade}

Considera-se Reforma Agrária o conjunto de medidas destinadas a "estabelecer um sistema de relaçóes entre o homem, a propriedade rural e o uso da terra, capaz de promover a justiça social, o progresso e o bem-estar do trabalhador rural e o desenvolvimento econômico do país, com a gradual extinção do minifúndio e do latifúndio" (Lei 4.504/64, art. 16).

Capta-se do conceito legal que a Reforma Agrária tem como premissa o fato de que tanto os latifúndios como os minifúndios são modelos indesejados de propriedade. E já se sabe, porque isso foi dito no item anterior, que, enquanto os primeiros concentram a propriedade e são geralmente improdutivos, os segundos não propiciam à família agricultora um mínimo existencial.

A Reforma Agrária tem assento constitucional, conforme previsão do art. 184 e ss. do Texto de 1988. Encartada no Título da Ordem Econômica e Financeira, ela concorre decisivamente para o atingimento dos objetivos da nação brasileira, constantes no art. $3^{\circ}$. do mesmo Texto e que repousam na construção de uma sociedade justa, livre e solidária, na garantia do desenvolvimento nacional, na erradicação da pobreza e marginalização, na diminuição das desigualdades sociais e regionais e na promoção do bem-estar de todos.

Por isso que alguns autores consideram a política reformista um direito humano fundamental (LIBERATO, 2004, p, 79). Ser fundamental significa que a Reforma no campo é obrigação do Poder Público, que deverá buscar mecanismos eficazes para implementá-la.

Importante registrar que, em várias passagens, os tribunais superiores do Brasil têm se referido à Reforma Agrária como direito da sociedade e dever do Estado. Emblemático acórdão do Superior Tribunal de Justiça assim se pronunciou a respeito das campanhas de invasão promovidas pelo MST no interior do Pais:

Pergunto se não seria uma reforma agrária de baixo para cima, uma pressão social, já que o governo está tranquilo há não sei quantos anos, quando todas as nossas Cartas e as nossas Constituiçóes estão apregoando a reforma agrária (STJ, 6ª . Turma, HC 4399, Rel. Min. Luiz Vicente Chernicchiaro, j. 12.mar.1996).

O que realmente interessa é a propriedade agrária cumprir sua função socioeconômica. Esta, consoante o art. 186 da Constituição, ocorre quando ela obedece a fatores 
econômicos, ambientais, trabalhistas e de bem-estar. Tal a condição que deve imperar no espaço agrário brasileiro. Ora, atingir um tal estado, diante de exacerbado número de latifúndios e minifúndios e dos conflitos pela posse agrária, só será possível com medidas reformistas.

\subsection{Mecanismos da Política de Reforma Agrária}

$\mathrm{O}$ art. 17 do Estatuto da Terra cataloga vários instrumentos para a efetivação da Reforma Agrária. São eles a desapropriação, a doação, a compra e venda, a arrecadação de bens vagos, a reversão da posse, a herança e o legado. A eles se pode aditar o confisco, previsto no art. 243 do Texto Constitucional.

O principal mecanismo desse cardápio legal é a desapropriação (INCRA, 2015). Esta consiste na aquisição da propriedade particular, mediante indenização paga pela Uniāo ao proprietário no prazo de vinte anos (CF, art. 184). Trata-se de desapropriação motivada por interesse social, que se verifica quando a propriedade não atinge sua função socioeconômica.

A desapropriação tem sido o meio escolhido pelo Poder Público para o implemento da Reforma Agrária. A lógica é simples: mostrando-se improdutivo o imóvel, o Estado o toma para si, indeniza o dono e entrega a área a pessoas interessadas na atividade agrária. O imóvel desapropriado é geralmente fracionado, de modo que várias famílias recebam pequenos lotes, onde são assentadas, recebendo título de uso ou de propriedade (Lei $8.629 / 93$, art. 18).

Apesar disso, é certo que a reforma da estrutura fundiária brasileira anda a passos muito lentos. Prova disso são os índices de violência de que se falou no item 1 e na constatação de que o contingente de latifúndios não tem decrescido. Ao contrário, no período de 2010 a 2014, experimentou um aumento de 2,5 por cento (INCRA, 2015). Isso revela que a Reforma Agrária, malgrado esteja sendo executada, não tem atingido os escopos eleitos pelo legislador.

Algumas variáveis podem ser mencionadas como entraves para a remodelação do perfil fundiário. Cita-se, por exemplo, a carência de recursos econômicos do Estado, que, embora implante o assentamento, não presta a devida assistência ao assentado. Este acaba por abandonar o imóvel ou ceder ilegalmente sua posse a terceiros. O último Censo de Reforma Agrária feito no Brasil revela que 40 por cento dos assentados abandonam suas terras já no primeiro ano de assentamento (MARQUESI: 2009, p. 176).

Todavia, um dos impedimentos para a consecução da Reforma Agrária está nos altos custos envolvidos na desapropriação. Sendo esta uma forma onerosa de aquisição, é necessário indenizar o proprietário, e indenizar pelo valor real da terra. Vale isso a dizer 
que uma política sólida e sustentável de desapropriaçôes envolve grandes inversóes de dinheiro, especialmente nos dias atuais, em que o valor da terra sobe a patamares elevados.

Alternativas devem, portanto, ser buscadas e uma delas é a concessão do direito real de superfície, sobre o qual se discorrerá abaixo.

\section{0 Direito de Superfície}

A correta compreensão do direito de superfície exige uma abordagem sobre seu conceito, natureza jurídica e efeitos, notadamente os poderes de que é investido o titular. Interessante é também examinar sua evolução histórica, o que permitirá uma melhor visualização pelo pesquisador. Acrescente-se que esse instituto, introduzido no Brasil há menos de quinze anos, não foi ainda de todo assimilado pela cátedra e pelas cortes.

\subsection{Conceito e Natureza}

O direito de superfície, disciplinado a partir do art. 1.369 do Código Civil, é tema relativamente recente no Brasil. Figura jurídica peculiar, suspende a eficácia do princípio de que o domínio das plantaçôes e construçôes incorporam-se ao domínio do proprietário do solo. Ela possibilita a existência, num mesmo espaço físico, de duas titularidades qualitativamente distintas: de um lado, a propriedade do solo; de outro, a das plantaçóes ou construçóes. Logo, estas pertencerão a um sujeito e o solo, a outro.

Um exemplo auxiliará na compreensão do conceito. Determinado produtor rural quer plantar uma área de eucaliptos numa região de clima e solo favoráveis. Procurando terrenos disponíveis, interessa-se por um deles e propóe ao proprietário a compra. Diante da negativa deste, acabam as partes por celebrar contrato de superfície, ajustando que o agricultor plantará no terreno, explorará as plantaçôes e, depois de vinte anos, entregará ao dono do solo o terreno florestado. Nesse exemplo, o superficiário será dono da plantação, e somente dela, pelo prazo de vintes anos, enquanto o solo permanecerá com o proprietário.

O que ocorre no direito de superfície é uma superposição de direitos reais, exercidos em diferentes dimensóes. Tem-se a propriedade do solo e, ao mesmo tempo, a propriedade das acessóes. Isso é uma excepcionalidade, pois, segundo a regra geral, se um terceiro planta ou constrói em terreno alheio, as acessóes se incorporam ao patrimônio do dono do solo (Código Civil, art. 1.253) Se for convencionada a superfície, as acessóes pertencerão ao terceiro (superficiário), enquanto o solo permanecerá com o proprietário original. Por isso, diz o recente Código Civil Argentino (2014), no art. 2.115, que el derecho del superficiario coexiste con la propiedad separada del titular del suelo. 
Há, com efeito, duas titularidades inconfundíveis, cada uma delas gerando direitos e obrigaçóes ao respectivo titular. Nesse sentido, vale conferir o Enunciado 321 da Jornada da Justiça Federal: "Os direitos e obrigaçóes vinculados ao terreno e, bem assim, aqueles vinculados à construção ou à plantação formam patrimônios distintos e autônomos, respondendo cada um dos seus titulares exclusivamente por suas próprias dívidas e obrigações, ressalvadas as fiscais decorrentes do imóvel”.

Significa isso afirmar que o instituto da superfície é composto de dois personagens, o fundeiro (dono do solo) e o superficiário.

Mas essa situação é transitória, pois o direito de superfície, ao contrário da propriedade e da enfiteuse, náo goza de perpetuidade, o que significa que ele, como a propriedade resolúvel, já nasce com o germe da própria morte.

Advindo o termo de vencimento, o superficiário necessariamente terá de entregar a construção ou plantação ao dono do solo, que assim adquirirá a propriedade sobre elas. Com a transmissão da titularidade superficiária ao fundeiro, que acontece de pleno direito ao final do prazo, resolve-se a superfície e consolida-se o domínio nas mãos do segundo, que agora passa a ser proprietário pleno.

Diante disso, pode a superfície ser conceituada como o direito real de plantar ou construir em terreno alheio, que concede ao seu titular, o superficiário, a propriedade resolúvel da plantação ou construção, temporariamente destacadas da domínio do solo.

Conforme elucida a doutrina (PINTO, 2000, p. 79), concedido o direito de superfície, ao superficiário pertencerá o edifício construído ou a plantação feita, continuando o solo a pertencer ao proprietário original, enquanto durar o prazo da concessão da superfície.

O art. 564-1 do Código Civil Catalão (1984) conceitua a superfície como "o direito real limitado sobre imóvel alheio, que atribui temporariamente a propriedade separada das construçóes ou plantaçóes instaladas no imóvel. Em virtude do direito de superfície, é mantida uma separação entre a propriedade da construção e da plantação e a propriedade do solo onde elas são feitas" (livre tradução).

Sua natureza jurídica é a de uma propriedade resolúvel, porque gera os mesmos direitos do art. 1.228 do Código Civil, mas se extingue ao final do prazo convencionado. Por isso alguns autores, como FARIAS-ROSENVALD (2008, p. 396), abordam-na como uma espécie de propriedade.

A superfície vem para substituir a enfiteuse, instituto jurídico que já não se afeiçoa à dinâmica do comércio jurídico e que, por isso mesmo, foi abolido pelo Código (art. 2.038). Dadas suas diferenças com o vetusto instituto, especialmente no tocante ao tempo de duração, que é sempre temporário, jamais perpétuo, abre ele novos horizontes nas titularidades reais, inclusive no tocante à função socioeconômica dos imóveis rurais. 


\subsection{Escorço Histórico}

A superfície tem berço romano e nasceu da necessidade de ocupação de espaços físicos, na medida em que aumentavam os domínios territoriais do Império conquistador. Já se percebe, desde suas origens históricas, objetivos de regularização de titularidades no espaço rural. Para a doutrina, tem ela origem nos usages, que eram as construçóes feitas pelos particulares romanos em terrenos públicos (GIRARD, 1906, p. 382).

Numa fase mais remota da civilização romana, a autoridade concedia aos particulares o direito de construir ou plantar em terreno público, à semelhança de um arrendamento por longo prazo. Numa fase posterior, os próprios particulares póem-se a conceder essa forma de arrendamento a outros particulares, disseminando assim as edificaçóes e plantaçôes. A faculdade de construir ou plantar em terreno alheio, contudo, não gerava ao titular um direito real, porquanto limitada ao campo obrigacional dos contratos e circunscrita ao princípio da acessão.

Com o passar do tempo, o pretor passa a conferir proteção possessória ao concessionário, através do interdito de superficiebus. Mercê da tutela interdital, a superfície acaba por assumir o caráter de um direito real, oponível erga omnes (ALVES, 2004, pp. 346347). Sob Justiniano (527-565 d.C.), o instituto firma-se como direito real sobre coisa alheia, como se vê do Digesto (XLIII,18,1). Ao superficiário são atribuídas ações reais, como a ação de superfície, semelhantes à reivindicação; a ação confessória, destinada a demonstrar sua titularidade e a ação negatória, para declarar a inexistência de ônus sobre a coisa (TEIXEIRA, 1993, p. 20).

$\mathrm{Na}$ Idade Média, o instituto conheceu, tal como a enfiteuse, enorme expansão. Isso se deveu, particularmente, a dois fatores: a influência da Igreja Católica, ávida de legitimar as construçóes que fizera em solo público e o caráter nômade dos povos bárbaros, a valorizar mais o trabalho que o solo onde ele se exercia. As incursóes germânicas e a consequente necessidade de defesa dos territórios impóem uma reorganização na forma de ocupação da terra, a gerar uma ruptura do modelo fundiário, agora baseado na superposição de domínios.

No medievo, vários titulares exercem poderes em graus diferentes, segundo o critério da concessão por títulos nobiliárquicos. Enfiteuse e superfície, por permitirem essa pluralidade de titulares sobre um mesmo imóvel, são os mecanismos que melhor atendem à nova ordem. Essa época assinala, inclusive, o nascimento da superfície sobre plantaçôes.

A disseminação do modelo superficiário e enfitêutico traz consigo, contudo, a servidão humana e a vassalagem, pelas quais o trabalhador se transforma num agregado da terra, devendo obediência irrestrita ao senhor feudal. A superfície do medievo, tal como a enfiteuse, é vista como atentatória da liberdade individual, razão pela qual o Código 
Napoleão, de 1804, para acentuar o exclusivismo do direito de propriedade e evitar um retorno aos perfis medievais, preferiu esquecê-las.

O advento do Código Civil Austríaco, em 1811, assinala o reingresso do instituto nos sistemas europeus, opção que é seguida pelos Códigos Holandês (1824), Alemão (1896), Suíço (1907), Italiano (1942) e Português (1966). França, Bélgica e Espanha admitiram-na em leis especiais. Na América Latina, o instituto está presente nas legislaçóes cubana, chilena, peruana e argentina (TEIXEIRA: 1993, p. 34).

No Brasil, a superfície vigeu desde o Descobrimento até 24.9.1864, quando foi abolida pela Lei 1.257. Influenciado pela legislação napoleônica, que consagra o absolutismo e a exclusividade do domínio, não a contemplou o Código de 1916, a despeito dos esforços da Comissão revisora para reintroduzi-la no sistema. O instituto somente renasceria em 2001, quando da ediçáo do Estatuto da Cidade, achando-se afinal positivado no Código Civil de 2002.

Colhe-se desse escorço que a superfície foi criada já com uma função socioeconômica, consistente na necessidade de ocupação de espaços físicos. E é esse potencial que a torna viável para as políticas de Reforma Agrária.

\subsection{Poderes de Ingerência Socioeconômica do Superficiário}

Constituído o direito de superfície, o superficiário adquire os poderes de uso, gozo, disposição e reivindicação da coisa. Pode ele, portanto, usar pessoalmente o imóvel, habitando-o ou então alugando-o ou dando-o em arrendamento. No caso de superfície sobre plantaçóes, poderá explorar pessoalmente o solo ou mesmo arrendar ou dar a cultura em parceria a um terceiro. Demais, pode transferir o direito, seja por venda, doação ou permuta, com isso deixando de ser superficiário.

É lícito ao superficiário, por outro lado, gravar de ônus as acessôes. Em razão disso, poderá hipotecar a edificação, empenhar a plantação e dar em penhora uma e outra. É-lhe lícito, também, criar direitos reais de gozo, como o usufruto e a habitação, sendo certo que, ao fazê-lo, deverá levar em conta a transitoriedade do direito.

No caso de transferência da superfície, por exemplo, o adquirente saberá que o direito adquirido tem duração limitada no tempo. Atingido o termo final da concessão, o adquirente entregará as acessóes do fundeiro. Como se adquire propriedade resolúvel, é claro que a venda se fará por baixo preço. Ocorrendo de o superficiário dar em hipoteca o imóvel, o credor terá a ciência de que a garantia se extinguirá de pleno direito ao final do contrato de superfície. Se o superficiário não pagar a dívida e a hipoteca for excutida, eventual arrematante também saberá que a aquisição se limita no tempo. Logo, arrematará a baixo preço também. 
É o que decorre do referido art. 1.369, que é complementado pelo art. 1.372 do Código: "o direito de superfície pode transferir-se a terceiros e, por morte do superficiário, aos seus herdeiros".

Quanto se tem transferência entre vivos, nenhuma remuneração será devida ao dono do solo, por força da vedação prevista no parágrafo único do art. 1.372. Ao proibir a remuneração do dominus soli nos casos de transmissão da propriedade superficiária, quis o legislador estimular o comércio jurídico e a circulação de riquezas, visando ao cumprimento da função socioeconômica dos imóveis. A superfície afasta-se, nesse ponto, da enfiteuse, que exigia o pagamento de um importe (laudêmio) sempre que o domínio útil fosse transferido.

Deve-se destacar, ainda, que, sendo o superficiário titular de direitos reais, tem ele posse sobre a coisa, razão por que poderá manejar os interditos para defendê-la, inclusive contra o dono do solo, que se mantém possuidor indireto, segundo a regra geral do art. 1.197 .

Como claramente se percebe, a superfície se aproxima da propriedade, com a importante diferença de ser transitória.

Analise-se agora seu potencial nas políticas de Reforma Agrária.

\section{Possibilidade de Aplicação da Superfície na Reforma Agrária}

A superfície, já se vê, tem um forte potencial para o cumprimento da função socioeconômica dos imóveis rurais. Apesar disso, não está ela prevista como mecanismo para execução da Reforma Agrária, como se observa do art. 17 do Estatuto da Terra.

O Código Civil Brasileiro, a primeira codificação civil do Séc. XX, busca adaptar os direitos reais às demandas da contemporaneidade, tratando a propriedade e seus desmembramentos como uma relação jurídica geradora de obrigações. Como a superfície é uma forma de propriedade resolúvel, ou ao menos se assemelha a ela, resta claro que ela está voltada para o funcionamento dos imóveis, notadamente os rurais.

Nesse diapasão, FIÚZA (2005, p. 1.259) argumenta que a superfície está ligada à função socioeconômica e ambiental que os bens desempenham nos dias de hoje. Segundo diz, "a mola propulsora do direito de superfície é, sem dúvida, o incremento da função social da propriedade e o seu enquadramento para um determinado fim, em sintonia com os preceitos sócio-econômicos, políticos e jurídicos, e com o estado democrático de direito”.

No âmbito urbano, é certo que o instituto em apreço pode desempenhar grande papel funcionalizante. Como claramente se extrai do art. 182 e ss. do Texto Constitucional, um dos objetivos da Política Urbana é o de ocupação de espaços físicos. De fato, pelos 
seus múltiplos problemas econômicos, sociais e ambientais, a lei combate os imóveis não utilizados, a ponto de punir o proprietário omisso.

Sendo a superfície um meio que permite a ocupação de espaços ociosos, encaixa-se ela com perfeição ao sobredito art. 182. Naqueles casos em que o proprietário de terreno urbano não tem condiçóes econômicas de edificar, poderá ele, ao invés de alienar o bem, dá-lo em superfície, conservando consigo, portanto, a propriedade do solo. Assim, quem dará uma função ao bem será o terceiro.

Com isso, fica assegurado o cumprimento da função social urbana e o proprietário segue como proprietário.

No ambiente rural, aplica-se idêntica ordem de ideias.

A questão agrária é, no Brasil, problema complexo, tanto mais porque compreende o conflito pela posse da terra, contrapondo os proprietários a grupos ideológicos como o MST. Como foi dito, o Estatuto da Terra, ao lado da Lei 8.629/93, elegeu a desapropriação como meio para realizar a Reforma Agrária e assentar pessoas à terra. Trata-se, contudo, de mecanismo demorado e extremante caro, na medida em que envolve processo administrativo e judicial e indenização ao sujeito desapropriado, de acordo com o valor venal do imóvel.

Se ao invés da desapropriação, o Estado impusesse a superfície aos imóveis rurais não cumpridores da função socioeconômica, os gastos com a Reforma Agrária seriam sensivelmente reduzidos, pois não haveria a necessidade de indenizar o proprietário desapropriado, ou então menor seria a indenização, eis que o domínio se conservaria com ele. De fato, este permaneceria proprietário, mas o imóvel seria usado por assentados, que depois o devolveriam.

Relembre-se que, sendo a superfície direito real e temporário, que confere os mesmos poderes da propriedade, ela permitiria ao assentado, por exemplo, financiar a produção e dar em garantia a plantação. O crédito seria mais acessível do que nas hipóteses de concessão de uso, em que o possuidor não é proprietário das acessóes. Além disso, o imóvel poderia ser transferido sucessivas vezes, beneficiando um número considerável de agricultores.

Isso não é possível nem nos institutos geradores de direito pessoal, como o arrendamento, nem nas formas de concessáo de direto real, como o direito de uso, previstos na Lei 8.629/93. Estes possibilitam apenas o exercício da posse, mas náo implicam poderes de propriedade. Logo, neles não pode o titular empregar a coisa em garantia nem transmiti-la, o que reduz o aproveitamento socioeconômico pelo assentado.

Diante disso, tem-se que a superfície traz duas vantagens nas políticas de reestruturação agrária. Primeiro, porque substituindo a desapropriação, isenta o Poder Público 
a qualquer indenização, liberando-o para investir recursos para, por exemplo, dar uma maior assistência ao assentado, seja para o incremento de sua atividade agrícola seja para a melhoria de seu bem-estar.

Em segundo lugar, a superfície apresenta vantagens porque confere ao assentado poderes de ingerência econômica sobre o bem, que não existem quando o assentado recebe concessão de uso.

Malgrado as possibilidades e vantagens que apresenta, o direito de superfície não tem recebido dos agraristas brasileiros a atenção que merece. Isso se deve a sua curta existência no ordenamento jurídico, já que a modalidade agrária só foi instituída em 2002. Há, contudo, algumas vozes que vêm se levantando em seu favor.

Nesse sentido,

para facilitar ou mitigar a sistêmica e endêmica falta de acesso à terra pelas populaçóes pobres - não só do Brasil mas de toda América Latina- o direito de superfície pode ser um meio de acesso à propriedade de tal modo que do ponto vista econômico seja um fator de estabilidade e, do ponto jurídico, seja o poder de fato transformado em poder jurídico (PACANARO; VELAZQUEZ: 2015, p. 18).

Diz, a propósito, VIANA (2002):

O Estado deveria se embasar no Direito alemão. Por exemplo, caso ele construísse casas, não precisaria dar todas aos pobres. A nossa reforma agrária é inútil, porque damos terras para os sem-terra. Daqui a pouco, eles vão se transformar em latifundiários. E os próximos sem-terra? $\mathrm{O}$ velho Prof. Waldemar Ferreira sabiamente dizia, há 50 anos, naquele tempo do compromisso, que o problema do Brasil não é dar terra ao home, mas dar o homem à terra. Hoje pergunto: será que é assim? Como está a terra? Está acabando. O problema do Brasil não é só dar terra ao homem. Se assim procedermos, teremos a produção cíclica e não haverá mais terra para dar.

Adiante, sugere (2002):

O Estado daria construiria grandes campos urbanos e, ao invés de dar, cederia o direito de superfície. A pessoa ocupa o terreno por certo período e depois transfere para outra, como os judeus, na sua sabedoria, faziam com o ano sabático: emprestariam as terras por certo período e elas iam passando de mão e mão, e a riqueza circulava.

E, como lapidarmente pondera PIFSTER (2007, p. 182), o direito de superfície é essencial para a preservação do ambiente natural e para a solução do problema da Reforma Agrária no Brasil. 
Diante disso, é de reconhecer o potencial socioeconômico da superfície. Tendo em vista tratar-se de um instituto ainda em desenvolvimento, não de todo assimilado pela sociedade e não utilizado pelo Poder Público, espera-se que, com o tempo, venha ele a ser amplamente empregado e praticado, notadamente na execução das políticas de Reforma Agrária.

\section{Conclusões}

Os problemas que afetam o ambiente fundiário brasileiro, e que compóem a chamada "questão" agrária, têm origem histórica e vieram se consolidando ao longo do tempo. Latifúndios e minifúndios são fruto de uma colonizaçáo que elegeu a grande propriedade, na forma de sesmarias, como propriedade padrão no território nacional e de uma legislação que náo conseguiu acomodar os interesses do colono desprovido de recursos econômicos.

O enorme contingente de latifúndios, em evidente concentração da propriedade agrária, pode ser apontado como a causa dos conflitos pelo acesso à terra, que se iniciaram no Século XIX e nos dias presentes.

A reforma da estrutura fundiária brasileira é uma necessidade reconhecida pelo Texto Constitucional e seu objeto é o de reduzir gradativamente as figuras do latifúndio e do minifúndio, o que geraria, além da reconfiguração do espaço rural, a diminuição da violência no campo. A Reforma Agrária atende aos ditames da Ordem Econômica e Financeira, previstos no art. 170 do Texto e concorre para o atingimento dos objetos da República do Brasil.

O principal instrumento empregado pelo Poder Público para a execução da política reformista é o da desapropriação por interesse social. O uso dessa ferramenta é, contudo, caro e complexo, envolvendo grandes inversóes de dinheiro. Isso faz com que a Reforma Agrária caminhe a passos lentos.

A introdução do direito de superfície viria em auxílio do Estado na execução da reconfiguração fundiária, porquanto apresenta a vantagem de não exigir o desembolso na desapropriação. Além disso, possibilitaria a ele maior poder de ingerência socioeconômica sobre o imóvel, que poderia ser dado em garantia para contrair financiamentos.

Diante de suas possibilidades e vantagens nas políticas de promoção da Reforma Agrária, o direito de superfície deve ser acolhido pelo ordenamento jurídico como um dos mecanismos das políticas fundiárias brasileiras.

\section{Sugestão de Lege Ferenda}

Considerando o que aqui foi exposto, sugere-se a positivação do direito de superfície na Lei 4.505/64 (Estatuto da Terra), cujo art. 17 ficaria assim redigido: 
Art. 17. O acesso à propriedade rural será promovido mediante a distribuição ou a redistribuição de terras, pela execução de qualquer das seguintes medidas:

(...)

f) concessão do direito de superfície

\section{Referências}

ALENCAR, Francisco A. G.; CUNHA, Gabriela B.; MATOS. Helaine S. Panorama dos conflitos e da violência no espaço agrário brasileiro de 1985-2014. Conflitos no Campo Brasil 2014. Goiânia: Comissão Pastoral da Terra, 2015. Edmundo Rodrigues Costa (coord.)

ALMEIDA JR., Jair. A Religião Contestada. São Paulo: Fonte Editorial, 2011.

BORGES, Paulo Torminn. Institutos Básicos do Direito Agrário. 10 ed. São Paulo: Saraiva, 1998.

BRASIL. Constituição da República Federativa do Brasil.

. Instituto Nacional de Colonização e Reforma Agrária (INCRA). www.incra. gov.br.

Lei 4.504/64. Estatuto da Terra.

. Lei 8.629/93. Lei Agrária.

. Lei 10.406/2002. Código Civil.

. Superior Tribunal de Justiça. 6a . Turma, Habeas Corpus 4.399, Rel. Min. Luiz Vicente Chernicchiaro, j. 12.mar.1996).

CARVALHO, Eduardo. Disputas pela posse da terra mataram 15 índios em 2013, diz CPT. http://globo.com/brasil/noticia/2014/04. Sítio consultado em 11.mai.2015.

CUNHA, Euclides. Os Sertôes. Rio de Janeiro: Record, 2000.

FARIAS, Cristiano C; ROSENVALD, Nélson. Direitos Reais. 5. ed. Rio de Janeiro: Lúmen Juris, 2008.

FAORO, Raimundo. Os Donos do Poder. V. 2. São Paulo: Globo, 1991.

FIÚZA, Ricardo. Novo Código Civil Comentado. 4. ed. São Paulo: Saraiva, 2005.

FREIRE, Paulo. Pedagogia do Oprimido. 17. ed. Rio de Janeiro: Paz e Terra, 1987.

GIRARD, Paul Frederic. Manual Élémentaire de Droit Romain. 4. ed. Paris: Arthur Rouseau, 1906. 
HOLANDA, Sérgio B. Raízes do Brasil. 26. ed. São Paulo: Companhia das Letras: 1995. LIBERATO, Ana Paula Gularte. Reforma Agrária. Direito Humano Fundamental. Curitiba: Juruá, 2003.

LIMA, Manuel O. O Movimento da Independência, 1821-1822. 6. ed. Rio de Janeiro: Topbooks, 1997.

MACEDO, Wellington. Chacina coloca o Pará na liderança dos mortes por conflitos agrários. Conlutas. Central Sindical e Popular. http://cspconlutas.org.br/2015/03. Sítio consultado em 11.mai.2015.

MARQUESI, Roberto Wagner. Direitos Reais Agrários e Função Social. 2. ed. Curitiba: Juruá, 2009.

MOGUEL, Julio. Reforma Constitucional y luchas agrarias en el marco de la transición salinista. Autonomía y Nuevos Sujetos Sociales en el Desarollo Rural. México: 1992, Século XX Editores. BOTEY, Carlota; HERNÁNDEZ, Luiz; MOGUEL, Julio (org.).

MOOG, Viana. Bandeirantes e Pioneiros. 11. ed. Porto Alegre: 1974.

MOREIRA ALVES, J.C. Direito Romano. 13 ed. Rio de Janeiro: Forense, 2004.

MST (Movimento dos Trabalhadores Rurais Sem-Terra). Concentração de terra cresce e latifúndios equivalem a três Sergipe. www.mst.org.br. Sítio consultado em 10.mai.2015.

PACANARO, Renato Franco; VELÁZQUEZ, Victor Hugo Tejerina. Função Social da Propriedade e Direito de Superfície. http://www.diritto.it/archivio/1/28362.pdf. Sítio consultado em 26,mai.2015.

PEIXOTO NETO, Pedro Accioly S. A luta contra o latifúndio: essencial na segurança alimentar e na sustentabilidade. Revista do Instituto do Direito Brasileiro. Ano 2 (2013), no. 13. http://www.idb-fdul.com

PFISTER, Milena Letícia. O Direito Real de Superfície: um dos instrumentos garantidores da função social da propriedade. Dissertação de Mestrado. Piracicaba: Unimep, 2007.

PINTO, Rosane Abreu Gonzales. O Direito Real de Superfície e a Sistemática do Novo Código Civil Brasileiro. Revista dos Tribunais. São Paulo. No. 775, pp. 79-95, mai.2000.

PRADO JR, Caio. Evolução Política do Brasil. Brasiliense, 1969.

TEIXEIRA, José Guilherme Braga. O Direito Real de Superfície. São Paulo: Revista dos Tribunais, 1993.

VARELLA, Marcelo Dias. Introdução ao Direito à Reforma Agrária. Leme: Led, 1998.

VIANA, Rui Geraldo Camargo. O Novo Código Civil Brasileiro. Seminário Câmara dos Deputados. Brasília, 05.nov.2002. 